\title{
Effective Factors for Increasing University Publication and Citation Rate
}

\author{
Masoomeh Shahbazi-Moghadam ${ }^{1}$, Hadi Salehi ${ }^{2}$, Nader Ale Ebrahim ${ }^{3}$, Marjan Mohammadjafari ${ }^{4}$ \& Hossein \\ Gholizadeh $^{5}$ \\ ${ }^{1}$ Perdana School of Science, Technology and Innovation Policy, Universiti Teknologi Malaysia (UTM), \\ Malaysia \\ ${ }^{2}$ Faculty of Humanities, Najafabad Branch, Islamic Azad University, Najafabad, Isfahan, Iran \\ ${ }^{3}$ Research Support Unit, Centre for Research Services, Institute of Research Management and Monitoring \\ (IPPP), University of Malaya, Malaysia \\ ${ }^{4}$ Department of Industrial Engineering, Kerman Branch, Islamic Azad University, Kerman, Iran \\ ${ }^{5}$ Department of Biomedical Engineering, Faculty of Engineering, University of Malaya, Kuala Lumpur, \\ Malaysia \\ Correspondence: Masoomeh Shahbazi-Moghadam, Perdana School of Science, Technology and Innovation \\ Policy, Universiti Teknologi Malaysia (UTM), Malaysia. E-mail: shahbazi_53@yahoo.com
}

Received: January 14, 2015 Accepted: June 10, 2015 Online Published: June 19, 2015

doi:10.5539/ass.v11n16p338 URL: http://dx.doi.org/10.5539/ass.v11n16p338

\begin{abstract}
Despite the vital role of paper publication and citation in higher education institutions (HEIs), literature on publication exercises is relatively scarce. There are a number of factors which influence the rate of university publications and citations. Accordingly, with a focus on policy perspectives, this paper discusses publication exercises by addressing the factors that can increase or decrease the rate of publication and citation in HEIs. The investigated zones are divided into two macro and micro levels, in which macro level deals with global policy and micro level is related to local and university policies. The effective factors and their relevant criteria are traced in all the aforementioned policies.
\end{abstract}

Keywords: academia, collaboration, higher education institutions (HEIs), publication impact, citation, university ranking

\section{Introduction}

Table 1. University as a system

\begin{tabular}{lll}
\hline Input (8M) & System & Output \\
\hline Man power & & Publication \\
Money & & Citation \\
Material & & Nobel prize \\
Method & Higher Education Institution & Branding \\
Management & & Reputation \\
Measurement & Patent \\
Milieu & Graduate student \\
Machine & & University ranking \\
\hline
\end{tabular}

As the cornerstone of modern science, the quality of research helps to determine reputational differences of scientific and academic institutions (Czellar \& Lanares, 2013; Fooladi et al., 2013). Systematically speaking, universities can be considered as a "knowledge production system" (Etzkowitz \& Leydesdorff, 1997; Godin \& Gingras, 2000) with a number of inputs and outputs (Table 1). One of the major outputs of educational organizations is to produce knowledge through publication and citation in high-indexed journals (Wu, 2013). 
Both at individual and scientific institutional levels, indicators such as number of papers and their citation rate in high-impact factor journals are traditionally used to measure scientific activities (García \& Sanz-Menéndez, 2005). While the individual level is briefly mentioned in this paper, scientific institutional level is discussed in relation to global, local and university policies, which are identified as environmental features.

\section{Background}

A review of literature indicates that university publication exercises are mostly investigated in studies focusing on how universities can raise public funds allocations. In addition, notwithstanding the fundamental role of research activity in higher education, research policy has not been much discussed in the literature on higher education (Metcalfe \& Ramlogan, 2008).

This paper generally deals with the literature on publication in terms of individual characteristics and environmental features. The subsequent brief overview mentions scholars' personality and enthusiasm to publish. Then, environmental features in publication exercises are addressed in the three aforementioned policies of macro and micro levels. Furthermore, as one of the indicators of HEIs performance, academic publication is investigated to highlight a list of effective factors and criteria in the three policy categories.

\section{Individual Characteristics}

Sociologists of science consider individual reputation and credit within scientific community as critical in diffusion of knowledge and emergence of social structure of science (Barber \& Merton, 1957; Cole \& Cole, 1967). For scientific ideas to circulate and scholars to be distinguished, there is a need to experience competition in research and undergo peer review (García \& Sanz-Menéndez, 2005). At a personal level, collaborative research requires time to be allocated by scholars (Bonaccorsi, Secondi, Setteducati, \& Ancaiani, 2012; Ponomariov \& Boardman, 2008). Academic reputation of a faculty member obviously depends on paper presentations, refereed journal publications as well as networking at high impact academic events (Noordin \& Jusoff, 2009).

\section{Environmental Features}

New systems have been devised by governmental and institutional organizations of higher education to measure research performance and efficiency since the emergence of entrepreneurial universities. Still, there are a number of issues to be considered: a lot of data, models and ways to be entrepreneurial as well as great complexity in applying assessment methodologies for heterogeneous scenarios (Cavaller, 2011). Regarding research outcome, one of the most common evaluation methods is to assess the rate and quality of publications.

Publication and citation have always been the center of attention for most universities (Ebrahim et al., 2013). Reasonable rate and sustainable improvement in academic publication and citation can be considered as HEIs final achievement. This is the way to rise in universities ranking, succeed in the battle for excellence, reach a world class university level, increase enrolment rate and develop the potentiality for reputation and branding. Therefore, any minimum changes in the three zones of global, local and university policies can seriously affect universities short-term and even long-term publication achievements (Figure 1). As Figure 2 shows, each zone has its own classification which is presented in details.

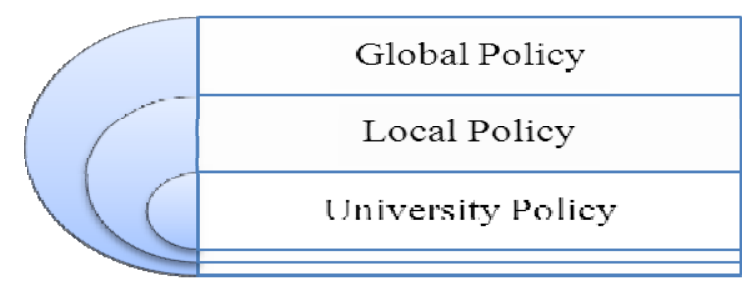

Figure 1. Influential policies on universities' publication exercise 


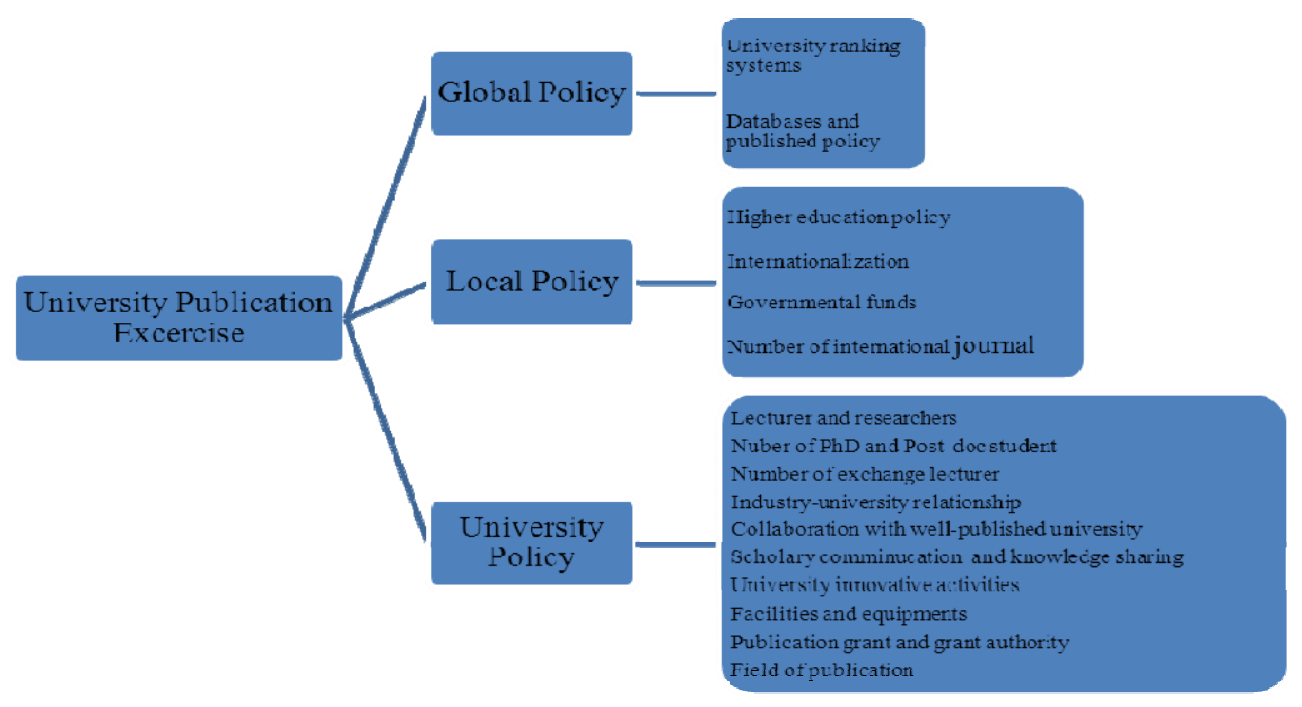

Figure 2. Related factors of policies influencing university publication exercise

\subsection{Global Policy}

Globalization has a significant impact on the function of higher education institutions in adapting to the rising and social requests for knowledge expansion, innovation and research proficiency (shahbazi, 2012). In recent decades, publication and citation measurement has become one of the most frequent demands from both public and private domains (Gault, 2011). Accordingly, academic publication is influenced by assessment policies such as University Ranking System, and Database and Publisher policies.

\subsubsection{University Ranking System}

The history of world university ranking goes back to the late nineteenth century in the United States and the annual report published between 1870 and 1890 (Salmi \& Saroyan, 2007; Rauhvargers, 2011). However, the forerunner of academic ranking of universities was the Institute of Higher Education of Shanghai Jiao Tong University. In 2003, a report entitled 'Academic Ranking of World Universities' (later referred to as ARWU) triggered a cut-throat competition by US and UK universities occupying the top 20 and top 100 lists. In reaction to ARWU, the Times Higher Education Supplement World Ranking commenced in 2004 as European evaluation for the rating of higher education institutes. As such, a global drive for ranking HEI has been launched (Shahbazi-Moghadam, 2012). Despite controversies about universities ranking systems, league tables provide HEI with a general indicator to analyze their systemic strengths and weaknesses and rethink their existing policies (Dill, 2006). In other words, policies reformations are essential for gaining international reputation, international students and governmental fund, which can be the outset for globalization and novel attitudes to international affairs. It is noteworthy that, among ranking indicators, Times Higher Education World University Ranking allocates $30 \%$ of the whole value of ranking to citation (Ale Ebrahim, Ebrahimian, Mousavi, \& Tahriri, 2015; Times Higher Education World University Rankings, 2015). Therefore, it can be recognized that publication and citation are vital for universities to maintain a good position or to be elevated in league tables.

\subsubsection{Databases and Publishers Policies}

The reputation of a journal being considered as Web of Science-indexed (formerly known as ISI-indexed) and remaining to be one is not limited to that journal. Not only does this affect other relevant journals but also it has an impact on universities' academic recognition. As articles are generally required to indicate academic affiliation, once they are accepted and published by high-impact journals, HEI naturally gain the credit as well. On the other hand, rejections and delayed publications have a reverse effect on the academic institutions. In fact, receiving rejection report after months is one of the obstacles which leads to lower rate of academia and their affiliations.

\section{Local Policy}

In terms of overall governance of national research system, there are two main functions for evaluation; research activity management and fund allocation. The first can be taken as a 'steering or management tool,' i.e. an instrument which organizes and manages research activities (Callon, 1996; Cruz-Castro \& Sanz-Menéndez, 
2007). As such, evaluation and improvement programs must focus on the function of research related organizations (e.g., universities, research centers and management institutions) and higher education policy making. The second is related to how government can allocate fund to HEI. While governments view research activity as a medium for economic development (Singh \& Allen, 2006), academic knowledge generation becomes strongly embedded within political economy (Gholizadeh et al., 2014; Marginson \& Rhoades, 2002; Rhoads \& Torres, 2006; Torres \& Schugurensky, 2002). Accordingly, local policies can be divided into Higher Education Publication Policy, Governmental Fund, Internationalization, and Number of International Journals.

\subsection{Higher Education Policy}

Slaughter (1998) believes that, at a national level, the higher education system is quite related to its local or home policies. Any short term or long term plan devised by higher education definitely influences universities policy making, vision and missions, which in turn has its impact on university publication exercises. Even in post-industrial countries, it is pivotal to depend "on higher education for training and research and greater development" (Slaughter, 1998). Also, research performed outside of academia depends on training and certification of scientists and technicians, which is a central function of higher education (Cohen, Nelson, \& Walsh, 2002).

\subsection{Governmental Fund}

Publicly funded academic research comprises a considerable portion of the whole research activity, which also has a positive effect on industrial research and development (Cohen, Nelson, \& Walsh, 2002). Besides introducing approaches of a market-oriented nature, public authorities have commenced using contracts and being performance-oriented so as to budget national higher education institutions and research organizations (Jongbloed, 2011). Research system essentially evaluates research practices at a regular basis (Cole \& Cole, 1973; Zuckerman \& Merton, 1971). Paper publication and awards have been extended to research fund allocation from governments or intermediary organizations (Chubin, Hackett, \& Treiman, 1991; Cruz-Castro \& Sanz-Menéndez, 2007). For instance, Table 2 illustrates the importance of academic publication for HEI in terms of funding criteria for some countries.

Table 2. Examples of particular countries funding criteria

\begin{tabular}{|c|c|c|}
\hline Country & Criteria for fund based on & Source \\
\hline Australia & $\begin{array}{l}\text { Graduate student numbers or completion rates, research } \\
\text { income, and publications, ... }\end{array}$ & $\begin{array}{l}\text { Jiménez-Contreras, De Moya Anegón, \& } \\
\text { López-Cózar, } 2003\end{array}$ \\
\hline Spain & $\begin{array}{l}\text { Publication in international journals with English } \\
\text { language, ... }\end{array}$ & z-Contreras et al., 2003 \\
\hline Finland & Publication points, weighted by impact factor, ... & Adam, 2002 \\
\hline EU & Having a good reputation for publications, ... & Bonaccorsi et al., 2012 \\
\hline
\end{tabular}

\subsection{Internationalization}

As an impact of globalization, higher education internationalization is a process which integrates international, intercultural and global dimensions into purposes, functions (teaching, research, and service) as well as higher education delivery both at institutional and national levels (Knight, 2010). Regarding HEI publication rate, this process can be enhanced by attracting international students' especially postgraduate students, by exchanging lecturers with other countries and by collaboration both with international universities and international companies.

\subsection{Number of International Journals}

The number of local and international journals in a country may have a great impact on the publication rate of that country. A comparison of the number of journals in a country with the publication rate of the same country indicates an obvious relationship between the two items; the more the number of international journals, the higher the rate of publication and citation. Table 3 and Figure 3 show the number of journals in all fields in four countries, based on The Scimago Journal and Country Rank (1996-2013) (http://www.scimagojr.com/). Table 4 and Figure 4 also demonstrate citable documents in all fields for the same countries. 
Table 3. Number of journals in all fields in four selected countries

\begin{tabular}{lllll}
\hline Year & Japan & Malaysia & Country & China \\
\hline 1999 & 496 & 15 & 44 & 379 \\
2000 & 494 & 14 & 44 & 383 \\
2001 & 478 & 13 & 42 & 389 \\
2002 & 476 & 11 & 43 & 443 \\
2003 & 465 & 11 & 41 & 467 \\
2004 & 458 & 11 & 41 & 494 \\
2005 & 455 & 12 & 44 & 511 \\
2006 & 462 & 14 & 55 & 530 \\
2007 & 476 & 19 & 61 & 515 \\
2008 & 490 & 30 & 70 & 530 \\
2009 & 520 & 47 & 78 & 578 \\
2010 & 526 & 60 & 91 & 594 \\
2011 & 531 & 69 & 92 & 612 \\
2012 & 537 & 75 & 87 & 582 \\
2013 & 535 & 82 & 86 & 590 \\
\hline
\end{tabular}

(Scimago), Copyright 2007-2015. Data Source: Scopus ${ }^{\circledR}$

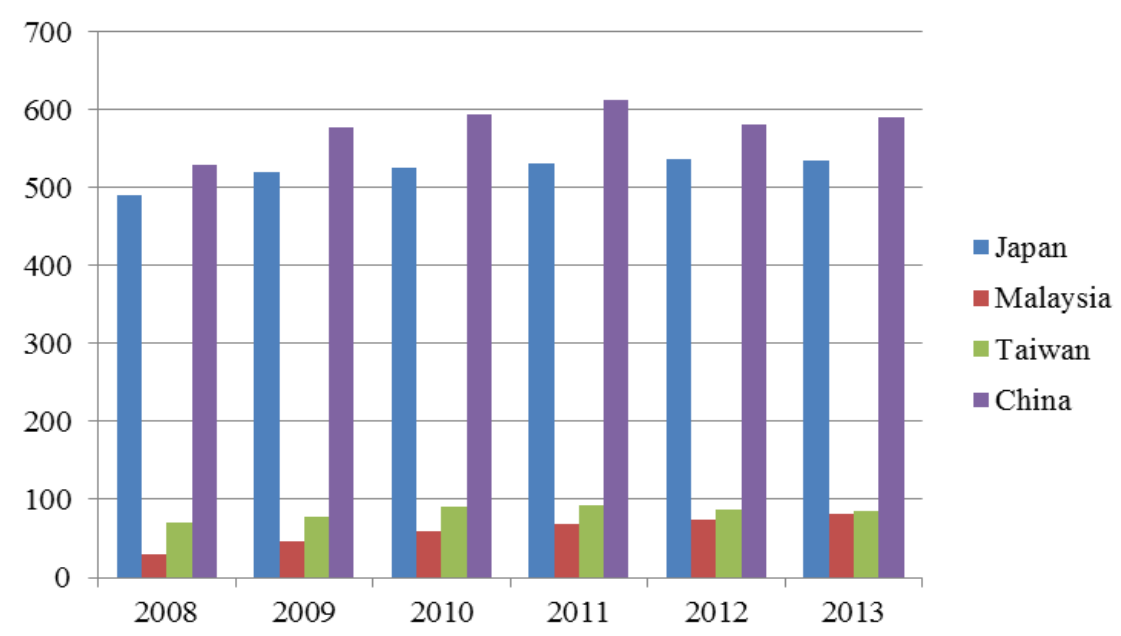

Figure 3. Number of journals in all fields in four selected countries from 2008 to 2013

Table 4. Comparison of different types of citations in four selected countries based on the total documents

\begin{tabular}{lllllll}
\hline Country & Documents & $\begin{array}{l}\text { Citable } \\
\text { documents }\end{array}$ & Citations & Self-Citations & Citations per Document & H index \\
\hline China & $3,129,719$ & $3,095,159$ & $14,752,062$ & $8,022,637$ & 6.81 & 436 \\
Japan & $1,929,402$ & $1,874,277$ & $23,633,462$ & $6,832,173$ & 13.01 & 694 \\
Taiwan & 446,282 & 434,662 & $3,993,380$ & 930,383 & 11.35 & 300 \\
Malaysia & 125,084 & 121,714 & 497,646 & 133,502 & 8.68 & 145 \\
\hline
\end{tabular}

Scimago Lab, Copyright 2007-2015. Data Source: Scopus ${ }^{\circledR}$ 


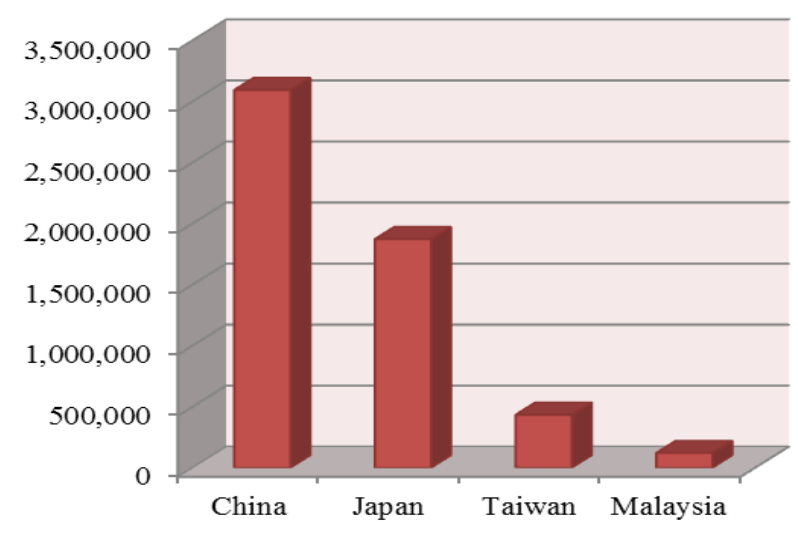

Figure 4. Number of citable documents in four selected countries

\section{University Policy}

University policy generally deals with university publication exercises. There are a number of factors which directly affect publication exercises once HEIs make changes to their counterpart policies. Among these factors, the present article focuses on some of the most important ones including number of lecturers and researchers, number of doctoral and post-doctoral students, number of exchange lecturers, university-industry relationship, publication grants and grant authorities, fields of publication, facilities and equipment, collaboration with well published universities, scholarly communication and knowledge sharing, and university innovative activities.

\subsection{Lecturers and Researchers}

As the main source of knowledge production, lecturers and researchers as well as the personal and academic qualifications of these individuals can influence rate and quality of publication. Besides academic qualification and experience, personal factors such as age, gender and teamwork abilities can affect the performance of academia in publication exercises. Hence, HEIs peopled with a desirable number of lecturers and researchers with outstanding expertise and sufficient experience can aim at generating high quality publication.

\subsection{Number of Doctoral and Post-doctoral Students}

Experimental sciences like life sciences involve doctoral students in experiments and knowledge production requiring the application of growingly complex instruments. Doctoral students are also considered as a vehicle for knowledge dissemination. With regard to publication, they circulate knowledge in academic organizations during and after their $\mathrm{PhD}$ program by contributing to scientific production and spreading knowledge to other organizations. Research conducted by doctoral students is an effective element in the overall knowledge production in universities. Therefore, training doctoral and post-doctoral students is actually a reproductive process in academic environments, which is linked with shifts in academic knowledge production (Enders, 2004). As such, institutional policy changes need to target improvement in funding system and increasing post-doctoral position. Conducting research in such a context demands competence as well as academic excellence, which in turn motivate an air of academic competition for knowledge enhancement and publication proliferation.

\subsection{Number of Exchange Lecturers}

Devising plans for collaborative work with universities at an international level involves exchange program with the purpose of Knowledge Transfer (KT), which results in high rate of publication. According to Cavaller (2011), knowledge transfer entails learning-teaching, diffusion and production of knowledge and patent and licensing. Hence, such activities not only improve quality management in academic research but also help the promotion of young talented researchers through international communication.

\subsection{University-industry Relationship}

Despite the importance adhered to the role of doctoral students in university-industry relationships, research literature is particularly limited in this regard. As to the nature of such roles, a doctoral student can significantly function as a knowledge producer in collaborative research projects (Mangematin \& Robin, 2003; Slaughter, Campbell, Holleman, \& Morgan, 2002) and as a channel for transferring knowledge between university and industry (Graversen \& Friis-Jensen, 2001; Mangematin, 2000). By doing doctoral and collaborative research 
respectively during and after graduation, these students become "bridge builders" between universities and industries (Borrell-Damian, 2009). However, their own research and training experience is mostly taken for granted both in the process of research experience and the context of collaborative research (Thune, 2010). Notwithstanding their focal role in university-firm relationships, student-firm interaction has been only slightly gone through systematic research. Due to changes in knowledge production process and labor market for degree holders as well as increasing university-industry interaction, there is a growing debate about new policies for prospective doctoral education (Thune, 2009). As for universities, once a collaborative research is completed and the outcome is generated as an article, both their publication rate and governmental fund allocation rise.

\subsection{Publication Grants and Grants Authority}

Due to their expertise, senior members of academia have to shoulder various responsibilities among them to assess grant applications. As such, distribution of research grants is generally determined in association with the evaluation made on research performance (Butler, 2004). Once it comes to some of the fields in social sciences, the problem arises from the fact that there are fields which face a more limited opportunity for ISI-indexed publications, hence a lower chance for research funding. As a result, decline of publication rate and grant approval maintain a negative reciprocal effect in some departments or faculties. Beside the crucial role of research grant in improving university publication rate, authorities in charge of grant approval are also of prime importance. For example, in some Malaysian universities, there are sometimes obstacles which restrict lecturers in specifying their research funds to international students.

\subsection{Field of Publication}

When it comes to university publication exercises, complications surround the actual practice of knowledge generation. For one thing, although both books and articles can be the outcome of academic research in higher education, their impact on scholarship is not necessarily equal. Articles, rather than books, are required for promotion and tenure process. As such, journal papers are the primary "objects" of study in the ISI Web of Science database. Due to the growing tendency for the publication of articles rather than books, which offers the benefit of brevity and saving time, academic science has the potentiality to shape or even reshape not only the technological interface of the Web of Science but also the consideration of articles as measure for productivity. Over time, as scholars begin to adjust to these shifting norms, privileging articles over books may be prone to negatively affect the type and quality of higher education research. Moreover, as already mentioned, publication and citation rate seem to be interconnected with the field of study. Based on 'Master journal list' in June 10, 2015, the number of ISI-indexed journals for Art and Humanities, Science, and Social Sciences is 1755, 8739 and 3208, respectively (Table 5). It may be high time for researchers to devise a political economic framework to protect production practices and to take control of the academic enterprise (Metcalfe, 2008).

Table 5. Number of ISI-indexed journals based on the field of publication (Source: Web of science)

\begin{tabular}{ll}
\hline Field of publication & Total journals $(\mathbf{N})$ \\
\hline Art and humanities citation index & 1755 \\
Science citation index expanded & 8739 \\
Social science citation index & 3208 \\
\hline
\end{tabular}

\subsection{Facility and Equipment}

Faculty productivity through publication and citation rate, especially in fields of science, medicine and engineering is undeniably influenced and promoted by facilities in general and lab equipment in particular. As potential centers for knowledge diffusion, well-equipped universities can attract researchers individually as well as collaboratively both at local and international levels. Therefore, once the facilities are improved, knowledge generation and collaborative research better contribute to university publication exercises.

\subsection{Collaboration with Well-published Universities}

Besides effecting fund allocations, collaborative work with other HEIs has a direct influence on increasing publication rate. Collaboration with well-published universities acts like a benchmark in improving high quality publication (see Table 6 \& Figure 5). As an example, EU funding is distributed based on individual projects. The evaluation of such projects depends, among some other factors, on relevant publications regardless of the mother university (Bonaccorsi et al., 2012). Legitimacy and reputation of HEIs as high-quality research centers thus rely on the academic recognition of their leading scientists in various disciplines (García \& Sanz-Menéndez, 2005). 
Theories of feasibilities are gained by competitions for research and publication so that HEIs are credited once research discoveries are diffused. As a key aspect of research careers, it is of prime significance to be initiative in making discovery and to achieve peer recognition (García \& Sanz-Menéndez, 2005).

One of the profits resulting from international collaborative research is a higher citation rate (Narin, Stevens, \& Whitlow, 1991; Katz \& Hicks, 1997; Goldfinch, Dale, \& DeRouen, 2003; Glänzel \& Schubert, 2005). Several possible descriptions for this phenomenon including the sharing of resources, idea and expertise have been proposed. Moreover, it has been recommended that increased collaboration leads to larger number of self-citations, thus inflating citation rates. Studies have indicated that this alone cannot describe the higher citation rates resulting from international collaborations (Abt, 1984; Smart \& Bayer, 1986; Herbertz, 1995).

Table 6. Publication collaboration of China, Japan, Taiwan and Malaysia with other countries

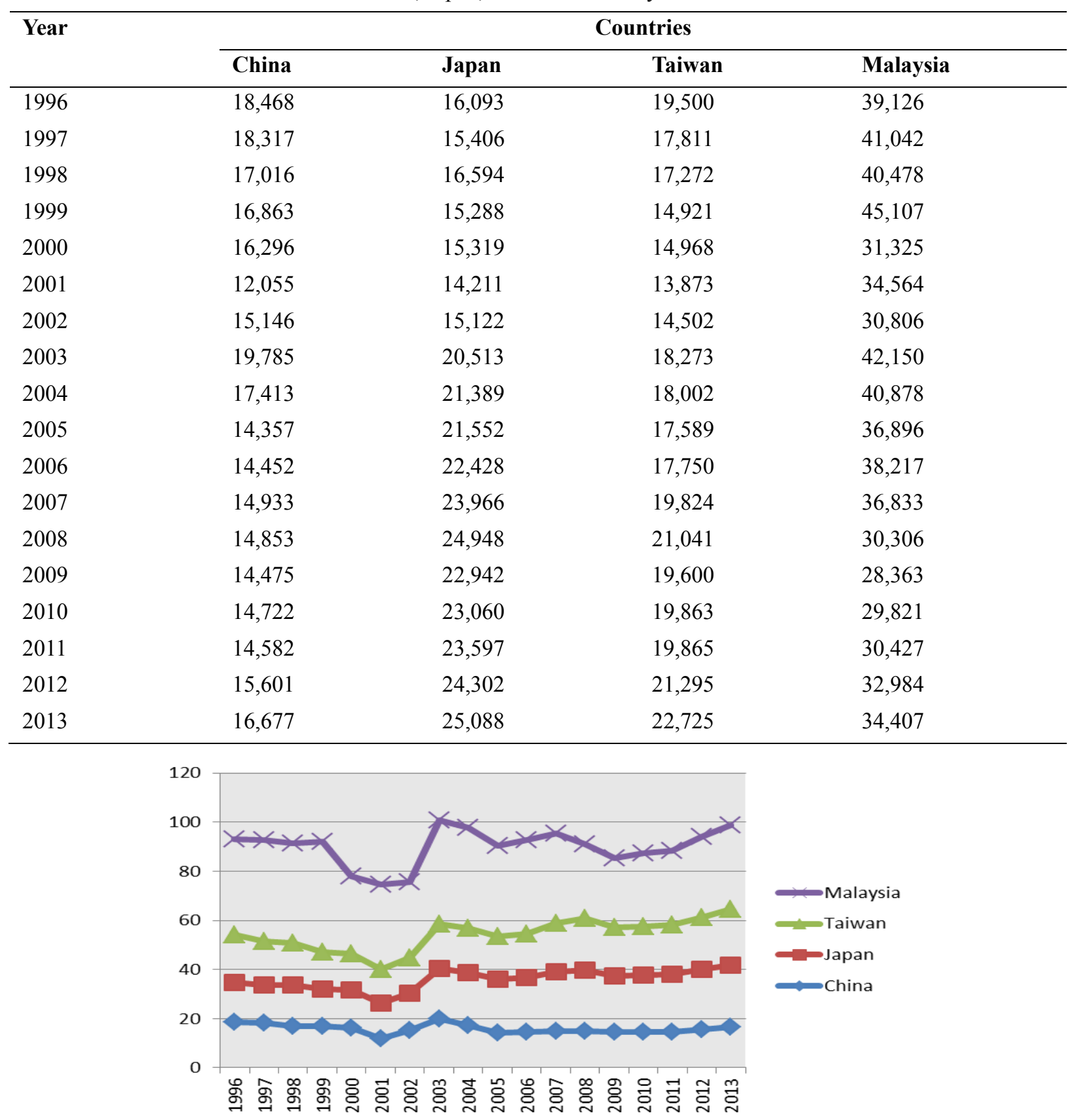

Figure 5. Publication collaboration of China, Japan, Taiwan and Malaysia with other countries 


\subsection{Scholarly Communication and Knowledge Sharing}

Knowledge sharing, both at local and international levels, can enhance willingness for publication among academia by scholarly communication. This particularly happens because of motivation inspired and produced for high quality research activities. In this regard, university can offer researchers and lecturers the chance of meeting experts in their respective fields and attending conferences as a way to be updated about novel ideas and fresh topics of their interest.

\subsection{University Innovative Activities}

As emphasized by Schartinger, Schibany, and Gassler (2001), the role of universities in society and economy is crucial not only in producing new knowledge but also in its dissemination. University publication is of prime importance because it is both in relation to knowledge generation and dissemination of new findings. As such, knowledge dissemination may be improved by innovative activities concerning the ease of publication process for academic staff members in order to motivate them for publication.

Individual characteristics and environmental features have some common qualities with each other. According to Luhmann (1992), reputation may be seen as the second selective code functioning in the system of science that aims to decrease the difficulty of the system. Reputation can become a social fact with regard to recruiting of students and scientists and to funding decision as well. Moreover, there are significant correlations among academic performance and reputation in academic communities (Federkeil, 2009). In his study about reputation indicators in rankings of HEIs, Federkeil (2009) showed that there is a correlation between publications and reputation in mathematics. Moreover, in some disciplines, reputation has a strong impact on the ability of the universities to get external research grants, in others to the number of doctoral students and in some to the number of publications.

\section{Conclusion}

As an indispensable part of HEIs, publication exercises demand constant attention and consideration of policy makers in order to meet the toweringly high expectations from both the academia and their affiliated universities. This paper was an attempt to highlight the various factors in terms of individual characteristics and environmental features which focus on all three policy perspectives of global, local and university level which are influential in HEIs publication exercises one way or another. As such, attention must be directed towards these factors, and measures should be taken in a way to help improvements in publication and citation rate by timely and appropriate policy-makings.

Methodically, this study and highlighted factors for each policy have been extracted from the related literature. That is obviously clear that the mentioned factors are not the only items which may affect the universities' publications. In fact, the highlighted elements for each policy have had the most frequency in comparison with the others in the literature. Therefore, factors with low efficacy have been eliminated in this study.

\section{References}

Abt, H. A. (1984). Citations to single and multiauthored papers. Publications of the Astronomical Society of the Pacific, 746-749. http://dx.doi.org/10.1086/131415

Ale Ebrahim, N., Ebrahimian, H., Mousavi, M., \& Tahriri, F. (2015). Does a Long Reference List Guarantee More Citations? Analysis of Malaysian Highly Cited and Review Papers. The International Journal of Management Science and Business, 1(3), 6-15.

Ale Ebrahim, N., Salehi, H., Embi, M. A., Habibi Tanha, F., Gholizadeh, H., Motahar, S. M., \& Ordi, A. (2013). Effective Strategies for Increasing Citation Frequency. International Education Studies, 6(11), 93-99. http://dx.doi.org/10.5539/ies.v6n11p93

Barber, B., \& Merton, R. K. (1957). Social stratification.

Bonaccorsi, A., Secondi, L., Setteducati, E., \& Ancaiani, A. (2012). Participation and commitment in third-party research funding: Evidence from Italian Universities. The Journal of Technology Transfer, 1-30.

Borrell-damian, L. (2009). Collaborative Doctoral Education: University-industry Partnerships for Enhancing Knowledge Exchange: Doc-Careers Project. European University Association.

Butler, L. (2004). What happens when funding is linked to publication counts. Handbook of Quantitative Science and Technology Research: The Use of Publication and Patent Statistics in Studies of S\&T Systems, 389-340.

Callon, R. W. (1996). Method and apparatus for routing for virtual networks. Google Patents.

Cavaller, V. (2011). Portfolios for entrepreneurship and self-evaluation of higher education institutions. Procedia-Social and Behavioral Sciences, 12, 19-23. http://dx.doi.org/10.1016/j.sbspro.2011.02.005 
Chubin, D. E., Hackett, E. J., \& Treiman, S. (1991). Peerless science: Peer review and US science policy. Physics Today, 44, 115. http://dx.doi.org/10.1063/1.2810292

Cohen, W. M., Nelson, R. R., \& Walsh, J. P. (2002). Links and impacts: The influence of public research on industrial R\&D. Management science, 48, 1-23. http://dx.doi.org/10.1287/mnsc.48.1.1.14273

Cole, J. R., \& Cole, S. (1973). Social stratification in science. University of Chicago Press Chicago.

Cole, S., \& Cole, J. R. (1967). Scientific output and recognition: A study in the operation of the reward system in science. American sociological review, 377-390. http://dx.doi.org/10.2307/2091085

Cruz-Castro, L., \& Sanz-Menendez, L. (2007). Research Evaluation in Transition. The Changing Governance of the Sciences. Springer. http://dx.doi.org/10.1007/978-1-4020-6746-4_10

Czellar, J., \& Lanares, J. (2013). Quality of research: Which underlying values? Scientometrics, 95(3), 1003-1021. http://dx.doi.org/10.1007/s11192-012-0928-x

Dill, D. D. (2006). Convergence and diversity: The role and influence of university rankings. In Keynote Address presented at the Consortium of Higher Education Researchers (CHER) 19th Annual Research Conference.

Enders, J. R. (2004). Research training and careers in transition: A European perspective on the many faces of the PhD. Studies in Continuing Education, 26, 419-429. http://dx.doi.org/10.1080/0158037042000265935

Etzkowitz, H., \& Leydesdorff, L. (1997). Universities and the global knowledge economy: A triple helix of university-industry-government relations. Pinter London.

Federkeil, G. (2009). Reputation indicators in rankings of higher education institutions. University rankings, diversity and the new landscape of higher education, 19-34.

Fooladi, M., Salehi, H., Yunus, M. M., Farhadi, M., Chadegani, A. A., Farhadi, H., \& Ebrahim, N. A. (2013). Do Criticisms Overcome the Praises of Journal Impact Factor? Asian Social Science, 9(5), 176-182. http://dx.doi.org/10.5539/ass.v9n5p176

García, C. E., \& Sanz-Menendez, L. (2005). Competition for funding as an indicator of research competitiveness. Scientometrics, 64, 271-300. http://dx.doi.org/10.1007/s11192-005-0251-x

Gault, F. (2011). Social impacts of the development of science, technology and innovation indicators. UNU-MERIT, Maastricht Economic and Social Research and Training Centre on Innovation and Technology. http://dx.doi.org/10.2139/ssrn.1949172

Gholizadeh, H., Salehi, H., Embi, M. A., Danaee, M., Ordi, A., HabibiTanha, F., ... Osman, N. A. A. (2014). Economic Growth and Internet Usage Impact on Publication Productivity among ASEAN's and World's Best Universities. Modern Applied Science, 8(5), 169-178. http://dx.doi.org/10.5539/mas.v8n5p169

Glänzel, W., \& Schubert, A. (2005). Domesticity and internationality in co-authorship, references and citations. Scientometrics, 65, 323-342. http://dx.doi.org/10.1007/s11192-005-0277-0

Godin, B., \& Gingras, Y. (2000). The place of universities in the system of knowledge production. Research policy, 29, 273-278. http://dx.doi.org/10.1016/S0048-7333(99)00065-7

Goldfinch, S., Dale, T., \& DeRouen, K. (2003). Science from the periphery: Collaboration, networks and 'Periphery Effects' in the citation of New Zealand Crown Research Institutes articles, 1995-2000. Scientometrics, 57, 321-337. http://dx.doi.org/10.1023/A:1025048516769

Graversen, E. K., \& Friis-Jensen, K. (2001). Job Mobility for the HRST Population: Implications and Evidence from Register Data?

Herbertz, H. (1995). Does it pay to cooperate? A bibliometric case study in molecular biology. Scientometrics, 33, 117-122. http://dx.doi.org/10.1007/BF02020777

Jiménez-Contreras, E., De Moya Anegón, F., \& López-Cózar, E. D. (2003). The evolution of research activity in Spain: The impact of the National Commission for the Evaluation of Research Activity (CNEAI). Research policy, 32, 123-142. http://dx.doi.org/10.1016/S0048-7333(02)00008-2

Jongbloed, B. (2011). Funding Through Contracts. Reform of Higher Education in Europe. Springer. http://dx.doi.org/10.1007/978-94-6091-555-0_11

Katz, J. S., \& Hicks, D. (1997). How much is a collaboration worth? A calibrated bibliometric model. Scientometrics, 40, 541-554. http://dx.doi.org/10.1007/BF02459299

Knight, J. (2010). Higher education crossing borders.

Luhmann, N. (1992). Die Wissenschaft der Gesellschaft. Frankfurt is Main.

Mangematin, V. (2000). PhD job market: Professional trajectories and incentives during the PhD. Research policy, 29, 741-756. http://dx.doi.org/10.1016/S0048-7333(99)00047-5

Mangematin, V., \& Robin, S. (2003). The two faces of PhD students: Management of early careers of French $\mathrm{PhDs}$ in life sciences. Science and Public Policy, 30, 405-414. http://dx.doi.org/10.3152/1471543037 


\section{9}

Marginson, S., \& Rhoades, G. (2002). Beyond national states, markets, and systems of higher education: A glonacal agency heuristic. Higher Education, 43, 281-309. http://dx.doi.org/10.1023/A:1014699605875

Metcalfe, A. S. (2008). Theorizing research policy: A framework for higher education. Higher Education. Springer. http://dx.doi.org/10.1007/978-1-4020-6959-8_8

Metcalfe, S., \& Ramlogan, R. (2008). Innovation systems and the competitive process in developing economies. The Quarterly Review of Economics and Finance, 48, 433-446. http://dx.doi.org/10.1016/j.qref.2006.12.021

Narin, F., Stevens, K., \& Whitlow, E. S. (1991). Scientific co-operation in Europe and the citation of multinationally authored papers. Scientometrics, 2, 313-323. http://dx.doi.org/10.1007/BF02093973

Noordin, F., \& Jusoff, K. (2009). Levels of job satisfaction amongst Malaysian academic staff. Asian Social Science, 5(5), 122-128. http://dx.doi.org/10.5539/ass.v5n5p122

Ponomariov, B., \& Boardman, P. C. (2008). The effect of informal industry contacts on the time university scientists allocate to collaborative research with industry. The Journal of Technology Transfer, 33, 301-313. http://dx.doi.org/10.1007/s10961-007-9029-z

Rauhvargers, A. (2011). Global university rankings and their impact. European University Association, Brussels.www.eua.be.

Rhoads, R. A., \& Torres, C. A. (2006). The university, state, and market: The political economy of globalization in the Americas. Stanford University Press.

Salmi, J., \& Saroyan, A. (2007) League tables as policy instruments: Uses and misuses. Higher Education Management and Policy, 19(2), 31-68. http://dx.doi.org/10.1787/hemp-v19-art10-en

Schartinger, D., Schibany, A., \& Gassler, H. (2001). Interactive relations between universities and firms: Empirical evidence for Austria. The Journal of Technology Transfer, 26, 255-268. http://dx.doi.org/10. 1023/A:1011110207885

Scimago, L. (2007-2013). Data Source: Scopus ${ }^{\circledR}$. Retrieved from http://www.scimagojr.com/compare.php?un $=$ countries\&c1 $=\mathrm{JP} \& \mathrm{c} 2=\mathrm{MY} \& \mathrm{c} 3=\mathrm{TW} \& \mathrm{c} 4=\mathrm{CN} \&$ area $=3300 \&$ category $=0 \& \mathrm{in}=\mathrm{it}$

Shahbazi-Moghadam, M. (2012). Globalization and Higher Education Policy. International Journal of Innovative Ideas (IJII), 12(2), 25-31.

Slaughter, M. (1998). International trade and labour-market outcomes: Results, questions, and policy options. The Economic Journal, 108, 1452-1462. http://dx.doi.org/10.1111/1468-0297.00353

Slaughter, S., Campbell, T., Holleman, M., \& Morgan, E. (2002). The "traffic" in graduate students: Graduate students as tokens of exchange between academe and industry. Science, Technology \& Human Values, 27, 282-312. http://dx.doi.org/10.1177/016224390202700205

Smart, J. C., \& Bayer, A. E. (1986). Author collaboration and impact: A note on citation rates of single and multiple authored articles. Scientometrics, 10, 297-305. http://dx.doi.org/10.1007/BF02016776

Thune, T. (2009). Doctoral students on the university-industry interface: A review of the literature. Higher Education, 58, 637-651. http://dx.doi.org/10.1007/s10734-009-9214-0

Thune, T. (2010). The training of "triple helix workers"? Doctoral students in university-industry-government collaborations. Minerva, 48, 463-483. http://dx.doi.org/10.1007/s11024-010-9158-7

Times Higher Education World University Rankings. (2015). World University Rankings 2014-2015 methodology. Retrieved from https://www.timeshighereducation.co.uk/world-university-rankings/2014 -15/world-ranking/methodology

Torres, C. A., \& Schugurensky, D. (2002). The political economy of higher education in the era of neoliberal globalization: Latin America in comparative perspective. Higher Education, 43, 429-455. http://dx.doi.org/ 10.1023/A:1015292413037

$\mathrm{Wu}$, J. (2013). Geographical knowledge diffusion and spatial diversity citation rank. Scientometrics, 94(1), 181-201. http://dx.doi.org/10.1007/s11192-012-0715-8

Zuckerman, H., \& Merton, R. K. (1971). Patterns of evaluation in science: Institutionalization, structure and functions of the referee system. Minerva, 9, 66-100. http://dx.doi.org/10.1007/BF01553188

\section{Copyrights}

Copyright for this article is retained by the author(s), with first publication rights granted to the journal.

This is an open-access article distributed under the terms and conditions of the Creative Commons Attribution license (http://creativecommons.org/licenses/by/3.0/). 